\title{
Decidual cast
}

\section{Smriti Gupta $^{1}$, Mamta Tyagi ${ }^{1}$, Renu Rana ${ }^{1}$, Anjali Gupta ${ }^{2}$}

\author{
${ }^{1}$ Department of Obstetrics and Gynaecology, Subharti Medical College, Meerut, Uttar Pradesh, India \\ ${ }^{2}$ Chief Medical Officer, CGHS, Meerut, Uttar Pradesh, India
}

Received: 23 October 2016

Accepted: 23 November 2016

\author{
*Correspondence: \\ Dr. Smriti Gupta, \\ E-mail: gupta_smriti_80@yahoo.in
}

Copyright: () the author(s), publisher and licensee Medip Academy. This is an open-access article distributed under the terms of the Creative Commons Attribution Non-Commercial License, which permits unrestricted non-commercial use, distribution, and reproduction in any medium, provided the original work is properly cited.

\begin{abstract}
Decidual cast describes the spontaneous sloughing of endometrium as an entire piece while retaining the shape of endometrial cavity. 15 year old girl presented to the outpatient Department of Obstetrics and Gynaecology, Subharti medical college in September 2015 with complaints of heavy menstrual bleeding since the onset of menstruation. On examination her vitals were stable and there was mild pallor. Systemic examination was found to be normal. All her investigations were within normal limits. She was give iron supplementation and was started on low dose combined oral contraceptive pills. Every woman should obtain detailed information about the possible side effects of hormonal therapies including endometrial cast discharge.
\end{abstract}

Keywords: Contraceptive pills, Decidual cast, Endometrium

\section{INTRODUCTION}

Decidual cast describes the spontaneous sloughing of endometrium as an entire piece while retaining the shape of endometrial cavity. ${ }^{1}$ Membranous dysmenorrhea presents as severe cramping pain due to the passage of this intact endometrial cast through an undilated cervix. The exact etiology of decidual cast is not known. Here we present the case of an adolescent who presented with decidual cast and membranous dysmenorrhea after being started on combined oral contraceptive pills.

\section{CASE REPORT}

15 year old girl presented to the outpatient Department of Obstetrics and Gynaecology, Subharti medical college in September 2015 with complaints of heavy menstrual bleeding since the onset of menstruation. On examination her vitals were stable and there was mild pallor. Systemic examination was found to be normal. Her investigation revealed moderate anaemia with haemoglobin of $9 \mathrm{gm} / \mathrm{dL}$. Her thyroid function test and coagulation profile revealed no abnormality. Her ultrasound too was found to be within normal limits. She was give iron supplementation and was started on low dose combined oral contraceptive pills. After the first course of 21 day combined oral contraceptive pills, the girl presented to us with severe dysmenorrhea. She had tachycardia though rest of her vitals were stable. On abdominal examination, uterus was $14 \mathrm{wks}$ gravid size uterus. We immediately performed urine pregnancy test which was negative. Injectable antispasmodics were given to her but to no avail. She then passed a fleshy sac like mass per vaginally and was immediately relieved of her pain after that. Her tachycardia settled and abdominally uterus was no more palpable. The expelled mass was globular sac like mass measuring $9 \times 7 \times 2 \mathrm{~cm}$. Both lateral surfaces showed 2 tube like structures which were each $4 \mathrm{~cm}$ long. This mass on histopathological examination revealed microscopic findings consistent with decidual cast. Also genital tuberculosis was diagnosed. She was started on antitubercular treatment and her menorrhagia subsided after that. 


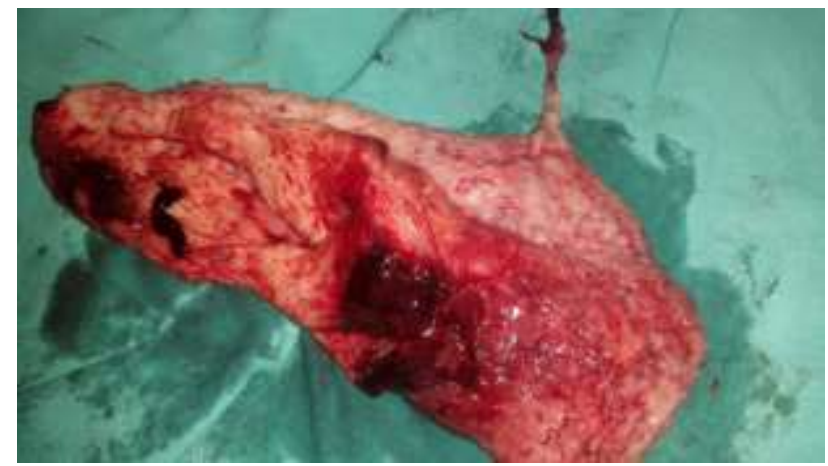

Figure 1: Decidual cast shed by patient.

\section{DISCUSSION}

Decidual cast describes the spontaneous sloughing of endometrium as an entire piece while retaining the shape of endometrial cavity. It may be associated with increased serum progesterone levels and must be considered as a differential diagnosis in a patient who passes tissue per vagina while on progesterone containing hormonal contraception. ${ }^{1}$ This condition is seen mainly in young women between 20 and 40years. Dysmenorrhea may or may not be present. Most of the cases had a history of hormonal therapy, but cases without hormonal therapy were also reported. ${ }^{2}$ In our case a young girl $15 y$ rs old presented with severe dysmenorrhea. Exact etiology is not known but excess of progesterone seems to play an important role. Membranous dysmenorrhea has a good prognosis, a low rate of recurrence and does not seem to be associated with negative consequences in long term. Every woman should obtain detailed information about the possible side effects of hormonal therapies including endometrial cast discharge. ${ }^{3}$

\section{Funding: No funding sources}

Conflict of interest: None declared

Ethical approval: Not required

\section{REFERENCES}

1. Malik MF, Adekola H, Porter W, Poulik JM. Passage of decidual cast following poor compliance with oral contraceptive pill. Fetal Pediatr Pathol. 2015;34(2):1037.

2. Upasham PS, Sirmukaddam SV, Sharan A. A Dysmenorrhea membranacea: A case report and review of the literature. Fertil Sci Res. 2014;1:56-7.

3. Nunes RD, Pissetti VC. Membranous dysmennorheaCase report. Obstet Gynecol cases Rev. 2015;2:042.

Cite this article as: Gupta S, Tyagi M, Rana R, Gupta A. Decidual cast. Int J Reprod Contracept Obstet Gynecol 2017;6:313-4. 